\title{
City Repositioning and Competitiveness Building in Regional Development: New Development Strategies of Guangzhou, China
}

Jiang XU and Anthony G.O. YEH

Centre of Urban Planning and Environmental Management

The University of Hong Kong

Pokfulam Road, Hong Kong SAR

jiangxu@hkucc.hku.hk and Anthony.Yeh@hkucc.hku.hk

Submitted to International Journal of Urban and Regional Research First Submitted on 22 July 2003

Revised and Re-submitted on 10 August 2004

Final revised submitted on February 2005 


\title{
City Repositioning and Competitiveness Building in Regional Development: New
} Development Strategies of Guangzhou, China

Jiang XU and Anthony G.O. YEH*

\begin{abstract}
Competition among cities for mobile capital in the 21st century has intensified. Urban hierarchy of a region is undergoing transformation, where economic fortunes vary markedly among different localities. In China, these global forces and regional restructures have caused a relative economic decline of some historically powerful cities, and have also brought about the emergence of new economic centres. In response to these forces, many Chinese cities have been driven into adopting a series of new competitive strategies, which seek to win back and build up their leading positions and competitiveness. To translate these strategies into concrete actions, local governments have promoted high profile and face-lifting projects and investments. The extensive new urban development in Guangzhou is a particularly interesting case. As the provincial capital of the Guangdong Province, and a historically central city in the Pearl River Delta Region, Guangzhou's importance has recently declined. This paper attempts to reveal the general strategies and specific projects initiated by Guangzhou as important promotion devices in its revitalization program, and to examine the rationales behind them. The ambitious new strategies could most likely happen under the 'soft budget constraint' syndrome in China, and these strategies could be risky. Although how much these strategies actually do stimulate business and lure investment is yet to be seen, the citizens are immediately and directly benefiting from them, and thus, they have gained much popularity and support. However, the competitiveness building in Chinese cities has called into question the legitimacy of local state governance, and the validity of large projects that lack financial disciplines, social objectives, and accountability for unsuccessful investments.
\end{abstract}

\footnotetext{
* The Centre of Urban Planning and Environmental Management, the University of Hong Kong, Pokfulam Road, Hong Kong. The authors would like to express their gratitude to the anonymous reviewers for their very constructive comments.
} 


\section{Introduction}

Globalization has been commonly identified as a strong and growing force in re-shaping the production and commercial activities in cities today. The global restructuring has generated a new regime of capital accumulation, with significant policy implications for various localities. At the international level there has been a global shift of industrial capital from developed countries to the less developed world (Dicken, 2003). At the national and regional level, traditional economic cores have been outshined by emerging new space economies, such as “edge cities” (Garreau, 1991) and "new industrial districts" (Scott, 1988). At the city level, the local order is subject to fundamental restructuring in a period when footloose capital is no longer tied to traditional urban economies (Short et al., 1993). Further down the hierarchy, economic fortunes contrast markedly with the attraction of new capital investment varying over space and city (Short et al., 1993: 207).

One important consequence is a growing trend, "towards greater (urban) entrepreneurialism, more intense inter-urban competition and the conscious promotion of place-specific development strategies" (Parkinson and Harding, 1995: 67; Harvey, 1989). Competition becomes so intense and inherent in local development that cities have to take a more entrepreneurial stance in order to remain at the top of a region, and enhance its attraction to the footloose capital, residents, and visitors (e.g. Harvey, 1989; Jessop, 1998). The effects of this change have large policy implications. A number of new forms of urban governance, such as entrepreneurialism (Harvey, 1989), "new urban politics” (Cox, 1995), "growth machine” (Logan and Molotch, 1987), and "urban regime” (Stoker, 1995) have emerged. Cities have adopted pro-growth strategies through "place marketing or promotion” (Kotler et al., 1990), “civic boosterism” (Ashworth and Voogd, 1990), prestige projects (Loftman and Nevin, 1996), or mega events (Hiller, 2000). It seems that capitalist cities are keen on adopting risk-taking and profit-motivated strategies to promote local and economic growth through active pursuit of infrastructure projects for attracting private investment.

Entrepreneurial strategies are also identified in post-socialist cities in the climate of inter-city competition (Herrschel, 1998; Young and Kaczmarek, 1999; Wu, 
2000a, 2000b). However, there are many variations among different cities in the contexts and rationales behind the development of such strategies and how they are implemented. This is particularly relevant to countries like China, where, as argued by Wu (2000a: 349), the entrepreneurial governance is constrained by the legacy of state socialism and the strong involvement of the state in the formulation and implementation of local development strategies. For instance, despite local governments becoming “entrepreneurial” in nature (Walder, 1995; Duckett, 1998), they are still under soft budget constraints, under which any possible loss of investment is not a matter of life and death because they can often be spared in one way or another from any loss making behaviour. To make things worse, because local governments are not real business firms per se, they do not have to go into bankruptcy even when local finances collapse (Zhao and Zhang, 2002). This has created a tendency of over-spending and unwise investment, regardless of capital cost (Jing and Zou, 2003). Because of this, local state investment has called into question the validity of large projects lacking financial discipline and the unenforceability of lossmaking threats. Under such circumstances, in which investment activities are undergone without sufficient consideration of genuine demand, bona fide financial capacity, and even capital cost, the "entrepreneurial nature” of local state may only exist in form but not in essence. The problem is also exacerbated by the commercialization of local financiers (Jing and Zou, 2003) and the dominance of government elites in decision making. These elites are more often than not urban boosters, advocating pro-growth strategies for both economic growth and their own career advancement. As a result, the rampant imitation, redundant construction, and speculations in Chinese cities, under the "snakes-and-ladders" game of inter-urban competition, are not uncommon. These observations inject a fresh counter argument in the predominant assertion that Chinese local governments now act like firms in developing business activities (e.g. Walder, 1995; Duckett, 1998; Wu, 2002). Yet, reforms have led to the creation of a more 'entrepreneurial local state' in the sense that the 'state' itself is a market player and can even use market instruments to achieve hidden political agendas. These features can be called major characteristics of an entrepreneurial state. However, reforms like 'scaling down the government' do not necessarily lead to the hardening of budget constraints of the local state. Rather, the local state becomes a 'unique’ market player, who does not care much about capital cost and market demand. Thus, true 'entrepreneurialism' is questionable. This paper 
develops this argument by showing how soft-budget constraint makes the local state not so 'entrepreneurial' in nature. More specifically, it shows how the state, lacking financial and social disciplines, goes beyond its budgetary constraints and social responsibilities to recklessly mobilize market resources for urban infrastructure development and its own political objectives.

Under these specific circumstances, three issues need to be addressed for a deeper understanding of the "repositioning behaviors" of many Chinese cities and their corresponding development strategies. First, what are the urban strategies preferred by local governments under intensive inter-city competition, and what are the rationales in adopting these strategies? Second, what are the urban impacts of these strategies and in what way do they contribute to urban transformation in the context afore specified? In particular, do they actually stimulate business, lure investment, and transform the economy for 'repositioning' purposes? Whatever the urban impact, there is increased awareness that the large property projects, in general, are vehicles for the materialization of development strategies and urban transformation in China (Wu, 1999). Physically, the substantial land and fiscal demands of these projects have typically resulted in some form of permanent alterations to the urban environment because they are often linked to massive land encroachment (Yeh and Li, 1999), inner city renewal (Gaubatz, 1999), and new area development (Yeh and Wu, 1996). From an urban governance perspective, since it is financially not feasible for local governments alone to undertake large projects, they have to rely on non-public investors (Wu, 1999). This encourages the building of coalitions based on money-generating sectors such as property. Sociologically speaking, large projects may lead to social conflicts as a result of the diversion of scare public sector resources away from welfare-related needs (e.g. education) to face-lifting projects, from the displacement of existing populations and land use functions, to accommodate ambitions of the local state. This problem is directly related to the third issue, which is: how are large projects justified by the local state to gain much popularity and support? Developing these projects are ideas of the local elite, who will ultimately utilize public resources, sometimes at the expense of affected residents. 
These issues also point to a critical question about the role of the state in urban development. To understand market reform as a complete retreat of state power from economic and social life would be too simplistic ( $\mathrm{Wu}, 2002)$. From a political economy stance, any given city can be conceived as the spatial expression of a variety of interests. The state, as one of the significant interests, always plays a major role in constituting economies, no matter how 'free' an economy may be (Block, 1994). In the United State's capitalist economy, the urban growth machine also captures urban government for dominant economic interests in many American cities. The theory interprets cities as places where coalitions of landowners, developers, and other interests, with a direct stake in the urban development, are strongly motivated to see their shared interests and to drive the urban 'growth machine' to benefit their own fortune building (Logan and Molotch, 1987; Molotch, 1990). Formation of coalition politics underlies many other discourses, and takes on various forms (e.g. urban entrepreneurialism, urban regime, growth coalition and new urban politics). These discourses suggest a state becoming increasingly preoccupied with the exploration of new ways in which to foster and encourage local development in a highly pluralist society, with strong social mobility power. They have immense appeal to Chinese scholars (e.g. Zhu, 2004) in the analysis of China's urban politics and local economic development, as they might shed light on the emerging governance in China: the role of state as regulator and player 'mobilizing and governing the market'. But how far does the Chinese local state deviate from discourses originating from free markets in advanced capitalism? This paper will attempt to answer this question, too.

Currently, there is a vast amount of literature pertinent to urban development in China, but very few focus on investment behaviors of local state and how these behaviors construct urban outcomes. Investment behaviors of Chinese local state are large project oriented, and have immense implications for urban change. This paper fills in the current academic gap by examining issues (e.g. the role of local state rationales and the outcome of new strategies) raised in this section, and contributes to a deeper understanding of local politics and urban growth in China, in both theoretical and practical terms. 


\section{Competitiveness and competitive strategies}

Despite of the ongoing worldwide debate on whether or not cities compete with one another (e.g. Krugman, 1996; Begg, 1999), Porter's competitive city concept (Porter, 1995, 1998) is one of the most influential discourses (e.g. Wang et al., 2001). In this concept, cities do compete with one another. Every location whether a nation, region, or city - has a set of unique local conditions that underpin the ability of companies based there to compete in a particular field (Porter 1998: 380). City-level competition does not fundamentally differ from operating at the national level. The "diamond" model ${ }^{1}$ is just as relevant to smaller geographic areas. This argument reinforces the idea that the local socio-economic environment is an indispensable source of growth dynamics. Competitiveness of a locality is thus determined by indigenous rather than external factors. This exerts great policy implications for various localities worldwide. The notion of cities as competing entities has now been widely accepted (e.g. Begg, 1999; Kresl and Singh, 1999; Cheshire, 1999). However, there is little agreement on what constitutes the “competitiveness” of cities and how local policy should aim to enhance it. Porter has emphasized productivity, formation of clustering, technological leadership, and public-private partnership in a locality's competitiveness (Porter, 1998). Competitiveness is also discussed in relation to new industries (Fagerberg, 1996); physical, human, and institutional capital (Begg, 1999); and sound economic growth with the ability to sustain the position in the urban hierarchy (Kresl and Singh, 1999).

The supply-side factors that contribute to a competitive urban economy have affirmed the role of policy action by governments in building competitiveness. Specifically, many city administrations have shifted from redistribution and provision to a more proactive entrepreneurial stance (Harvey, 1989; Fainstein, 1994; Loftman and Nevin, 1996; Begg, 1999). Cities are under increasing pressure to pursue effective competitive strategies if they are to prosper. Often used tactics combine the traditional property-oriented growth pattern, such as investment in projects with key control, and command functions in high finance, government, and information in the context for desired city status (e.g. airports, ports, and other related facilities to improve the quality of place) (Harvey, 1989; Loftman and Nevin, 1996; Fainstein, 1994). New city marketing schemes also orient both to image building and repackaging the 'place 
product' by emphasising the uniqueness of local identity (Kotler, et al., 1990; Ashworth and Voogd, 1990; Wilson, 1995; Jessop, 1998). Very often, the city marketing scheme also has to rely on property projects that require massive land occupancy to achieve its aims (e.g. convention and shopping centres as prominent facets for urban regeneration, or by identifying flagship projects with local significance) (Harvey, 1989). A central question is why property-led development has become, as argued by Harvey (1988), the most common feature of city revitalization schemes. In answering this question, Fainstein (1994: 2, also quoted in Loftman and Nevin, 1996) argues that,

\begin{abstract}
For policy-makers, encouragement of real estate development seems to offer a way of dealing with otherwise intractable economic and social problems. Governments have promoted physical change with the expectations that better-looking cities are better cities... The quandary for local political officials is that they must depend on the private sector to finance most economic expansion, and they have only very limited tools for attracting expansion to their jurisdictions. Their heavy reliance on the property sector partly results from their greater ability to influence it than other industries.
\end{abstract}

Against this global background in the study of competition, very few scholars in China have paid attention to inter-city competition until very recently. As a matter of fact, city competition is not a new phenomenon in the country. As argued by Huang (1996: 62), competition existed in a hidden form in the previous socialist state, but has become a public theme of urban governance since the 1980s. In particular, the growing international interests in competitive study and the desire of various localities in China to improve economic performance over the past few years have prompted searching questions about cities' competitiveness and the "right" policy responses (Huang, 1996). But what is 'competitiveness' in Chinese context? A widely cited definition by the China Academy of Social Science (CASS) describes city competitiveness as, "The relative ability of a city in comparison with other cities to attract, compete for, sustain, control, and utilize [capital] resources, and the ability to grab and control market in order to create value for the city and provide well-off to its residents" ( $\mathrm{Ni}, 2001:$ 1). This thesis of competitiveness as 'controlling ability for capital' helps to prioritize capital investors and economic efficiency over residents and social issues. Local governments are keener in building the ability to magnetize developers (Zhao, 2002a). Cities seek to promote themselves as locations for 
economic activities in competition with other areas. The impacts may be heterogeneous and unevenly experienced among different groups, such as those who hold capital sources and those who do not.

The emergence of competitiveness building in Chinese cities is built upon the foundation of allowing local financial flexibility and the de-centralization of the power of land disposal. The greater ability of the local state in finance and land disposal has led to its heavy reliance on the property sector in promoting growth (Wu, 1999, 2002; Zhu, 2004 and Zhao 2002a, 2002b). Since the economic reform in 1978, and especially after the land reform in 1988, local governments in China have increasingly seen large infrastructure projects (e.g. development zone), and propertyled development as an essential (and perhaps the only practical and readily available) mechanism for restructuring urban areas. They have also seen these projects as important city promotional devices (Yeh, 1985, Yeh and Wu, 1995; China Construction News, 2003). Such pro-growth approaches can play a role in developing economic confidence, rebuilding city images, and attracting inward investments (e.g. Castells and Hall, 1994). But it is also criticized for the lack of public accountability, social goals (Wilson, 1995: 648), and “cultural uniformity” among cities appealing to investors, professionals, and consumers (Harvard, 1989; Wilson, 1995). In a society where the local state is still under soft budget constraints (Zhao, 2002a, 2002b), a progrowth approach can lead to an overheated economy as a result of an over-heated property boom (Xu, 2004). This has called into question the validity of such an approach (China Construction News, 2003).

\section{Local government power and soft budget constraint: a 'reckless tiger with wings' in competitiveness building in China}

The emergence of various landed interests, an empowered local government, and changing urban governance is a well-recognized post-reform urban condition in China (Oi, 1995; 2000; Wu, 2002). Fiscal reform is generally identified as a milestone because it has redefined the financial responsibility of central and local states, to allow the latter greater financial flexibility and legitimacy in managing urban development through residual right (Zhang, 1999). Discussing the impact of fiscal reform, Zhao (2002a: 8) argues that, 
Local governments now enjoy much freedom within a clearly defined [financial] boundary, and are responsible for most of their own profits and losses; they are no longer worried that central government or other cities would snatch their resources away for the purpose of wealth redistribution; at the same time, they are supposed not to shirk off any loss-making activities.

Central government, however, still claims certain power in limiting local financial activities. For instance, local governments are not allowed to directly obtain bank loans or raise capital through issuing bonds so that they can keep a balanced capital revenue and expenditure allocation. ${ }^{2}$ This restriction serves as a major trigger for localities to utilize policy loopholes in order to raise funds for urban development (see below). As a popular Chinese saying goes, "for every measure from the top, a countermeasure at the bottom.” In sum, changes in local government finance and the decentralization of central power have meant that local governments have shifted from a passive agency of the centre to an active promoter and manager of urban development.

Land and housing reform is another milestone in engineering the changing role of local governments. After this reform, previously state-owned land and housing properties have become tradable products (Yeh and $\mathrm{Wu}$, 1996). In particular, "through enacting the Land Administration Law and City Planning Act, the state has defined the legitimate right of local governments, especially city governments in land development while allowing them to retain most income thus generated within their jurisdictions" (Zhao, 2002a: 8). In the arena of urban development, as de facto owners and managers of many critical resources (e.g. land), local governments' programmes have gone beyond the search for purely provisions, to a more broad-ranging attempt to restructure local growth by becoming major market players. However, much freedom in land disposal has also produced reckless city governments that resort to discrete and often illegitimate land requisition, land use (Xu, 2001; Nanfeng Windows, 2004), under-priced land leasing (Zhao, 2002a), rent-seeking, and corrupt behaviours (Nanfeng Windows, 2004). This is done in order to boost their fortune building and inflate political performance (Ba, 2003). It is achieved either through direct actions or by forming coalitions, whether in the name of 
local state corporatism (Oi, 1995), local state entrepreneurialism (Duckett, 1998), or in 'partnership’ with private real estate developers (Ba, 2003).

The changing role of local government has been further encouraged by the open door policy, which allows a chance of interaction between the local state and overseas investors. Unlike state-owned enterprises, overseas investors do not follow political orders and central commands to locate their production or services. In particular, as a city's client, they are footloose with much more locational flexibility (Zhao, 2002a); at the same time their demands for land resources are critical for local governments to form a competitive land market (Yeh and $\mathrm{Wu}, 1996)$. With a shrinking central budgetary allocation (Zhang, 1999), city governments are competing with each other to attract foreign investors. These investors are deemed as major sources of local and extrabudgetary income (e.g. local taxes and land income), among other benefits. The result has been a new style of management. Zhao (2002a) argues that there is a shift towards new practices, like making preferential policies that are customized to specific requests of foreign investors in competition with other localities. In general, there is a new emphasis on 'customer (investor) care' and on developing a commitment to a more 'business friendly' environment (Zhao, 2002a). Besides policy stimulants, a better business environment often means a better looking city that provides good infrastructure. This may serve as a rationale behind massive urban development in Chinese cities.

Empowered local state undoubtedly plays significant roles in urban development. It may, however, create economic and political problems. Probably one of the most important of these is competition and thus strong localisms in Chinese national politics. In the area of urban development, this has led to over-spending and unwise investment. An example is the Shanghai government's deliberate decision to move international flights and logistics services from the old Hongqiao Airport to the new but outlying Pudong Airport, in an attempt to snatch investors from nearby cities. ${ }^{3}$ The competing activities have been reinforced by the persistence of power of the local state in economic affairs (Oi, 1995), since the local state has much discretion over the use of critical resources, such as land (Wu, 1999) and credit (Holz, 1992; Oi, 2000). They can always find ways to circumvent central rules and regulations (Zhu, 
2004), and create difficulties for central control. This is perhaps a problem that the Chinese central government has been concerned with. In addition, because the root of China's society is entrenched in the previous state socialism, in which society was not ruled by laws but by party decree and powerful political elites, the mayor has great discretion in the area of urban development and planning ( $\mathrm{Xu}$ and $\mathrm{Ng}, 1998 ; \mathrm{Xu}$, 2001). Very often, it is the mayor who makes final decisions on important strategies and large projects. ${ }^{4}$ Furthermore, key local officials are appointed cadres. They have been rewarded for outstanding economic performance and physical achievement within their office terms. As such, they attach great importance to visual growth, both in economic and physical terms, to show their capabilities and to afford a chance for promotion in the government administration hierarchy (Zhu, 2004). For key local officials, urban development is less about functionality than it is about prestige (e.g. Cartier, 2002). Large projects are city symbols and are meant for impressing others. Officials are incredibly brand-conscious; many projects are designed by brand-name architects and planners from all around the world. These incentives in the country's officialdom have been identified as one major cause of rampant inter-city competition in making up ambitious plans and initiating landmark projects (Ye, 2001). This has led to the crux of the difficulties in curbing excessive investment and over-spending activities (Standards, 2004).

However, a central question is: how does the local state make excessive investment possible, and why it is not sensitive to capital costs as described by many observers (e.g. Xu, 2004)? The concept of soft-budget constraint may be useful to explain the investment activities of local governments. Soft budget constraint is often used to describe behavioral characteristics of firms when the strict relationship between expenditure (input) and earnings (output) has been relaxed (Kornai, 1986). These firms have two fundamental features. First, their poor performance and investment failures are not a matter of life and death. Second, they are not sensitive to cost because they lack the financial discipline that derives from the unenforceability of bankruptcy threats, with various bail-outs like subsidies, credits, and price supports (Kornai, 1986; 1992). This can be applied to explain the investment behaviors of Chinese local state in urban development. From the 'output' perspective, the failure of an investment project (e.g. the fancy Zhuhai International Airport fails to attract sufficient traffic volume) is not a matter of life and death for a city government. In 
fact, it might be helpful in boosting local economic growth (e.g. employment and GDP growth) and political performance. There is no strong incentive to minimize large projects if funds and land are available, because large cost overruns and investment failures never lead to the bankruptcy of the city administration and the end of an office term for the mayor.

From the 'input' perspective, local governments have a great deal of autonomy in disposal of two vital resources in urban development, i.e. land and finance. They are supposed to be self-sufficient, i.e. not only to cover expenditures from taxes and other revenues they are able to raise, but also to re-pay any debt that incurs. Unfortunately, some features of soft budget syndrome usually appear in both land and capital inputs. Let us examine the land element first. Under the current system, land income (e.g. from land leasing) or non-income benefits (e.g. from allocating land for face-lifting infrastructure projects and thus career advancement) are all captured by current city administrators during their terms in office. The negative effects of land shortage and misuse, the pressure of providing related infrastructure (e.g. electricity and road) and even compensation for land requisitions are the responsibility of officials during future terms in the city administration (Ba, 2003). Premiums from land leasing are essentially the sum of land rents for a number of years to come (Ba, 2003), which means that at least part of land income comes from further governmental sources. This brings about a phenomenon in which the inefficiencies and shortages caused by land overruns can be covered from future public spending. In the case of capital 'input', the situation is more complicated.

There are a number of ways to soften the budget constraints of local state. One way is through city governments' investment arms, such as the local International Trust and Investment Corporation (ITIC) and the Urban Development Corporation These are set up to undertake infrastructure construction, and more importantly, to raise funds from local and global financiers for large projects because local governments have limitations to do so. The main dilemma concerning the proliferation of such agencies is their insulation from effective state monitoring that may cause uncontrollable local debts. There is no sufficient legal framework to regulate their practices, and the relationships between them and their sponsoring city governments have not been clearly defined. It can be reasonably 
assumed that city governments 'own' and 'operate' these agencies, but it does not necessarily follow that the city governments are responsible for their debts (Emerging Market, 1999). For example, in the case of dealing with liquidity trouble, a city government may pass the trouble to the local ITIC by claiming to the creditors that the government has to retreat from the firm's operation, and thus the same ITIC has to take care of its own problems. Behind the scenes, there are a variety of financial methods available to bail the firm out, such as non-reimbursable subsidies from a government budget and public resources, as well as bank credits.

Another way to soften a local government's budget is through various financiers. Assistance from these financiers plays a key role in the city's competitiveness building because a local investment frenzy has often been reinforced by the commercialization of local banks or bank branches. Commercialization has enhanced the profit motives of lending operations (Jing and Zou, 2003), and thus helped to combine the vested interests of banks with those of the local governments to develop industries that would be more profitable to the localities (Holz, 1992; Oi, 2000). In many cases, refinancing bad projects is not uncommon (Sing Tao Daily, 2004). As the Chairman of the Bank of China explained, "Currently, almost 30\% of non-performing or bad loans of banks in China are caused by unwise policies of various [local] governments” (Hong Kong Commercial Daily, 2004). The four biggest state commercial banks ${ }^{5}$ were burdened with combined bad loans estimated at more than a fifth of total lending, or US\$232 billion (1.92 trillion RMB) at the end of 2003 (People's Daily, 2004). A central question is why the commercialization of banks has made them less, rather than more, risk averse? Originally, banks simply degenerated into mere agencies of the central state, taking care of the financial needs of state projects designated in the national economic plans (Holz, 1992). They served as a tool to re-distribute resources of the central state in the form of policy loans, and did not have to worry about profits and repayments. Financial reforms in the 1980s have made local banks entrepreneurial, with three prominent outcomes. First, banks have to go outside the state supply channels to attract deposits (Oi, 2000). Second, they have to rely on lending loans for profit margins and recapitalization. And third, without stabilized fund supplies from the upper level units, they have to compete with one another in taking any available funds (e.g. deposit) and approving quick loan applications to depositors (Oi, 2000). Under 
keen competition, banks will suffer if tightened loan assessment procedures lead to slow growth in their lending, hurting profit margins and delaying recapitalization (Wu, 2004). In China, the annual increase in bank deposits has exceeded the growth in the total amount of loans for many years (Zhao, 2002b). The perceived resultant phenomenon is capital surplus, leading to a continuing enlarged non-profitable asset of banks. Banks are thus keen to release deposits in the form of loans to projects they consider profitable or to those supported by local governments. As one official of the Bank of China argued, "Projects supported by governments are often welcomed by banks, because very few projects of this kind have big risks in repaying loans” (Hong Kong Commercial Daily, 2004). ${ }^{6}$ When state banks play a role in softening the budget constraints of the local state, the stringency of their own budget constraints is not yet available. The dual roles of these banks as administrative agencies of the state and as economic entities allow the central government considerable leeway, and excuses in sparing these banks in one way or another from losing behaviours. For example, in the early 2004, the Bank of China and Construction Bank obtained a US\$45 billion bailout from the central government to reduce their ratios of non-performing loans. This is an indirect way for local state to transfer investment risks to the central state, further softening the local budget in the game of competitiveness building.

The above discussions seem to suggest that if the local state runs into financial distress, it can hope to be bailed out by exteriorizing risk and getting direct assistance from higher level governments. As Zhao and Zhang (2002: 73) have outlined with great clarity:

Because of soft budget constraint and risk exteriorization
(pressure of re-paying debts and investment risks can be
transferred to central government through borrowing central
bonds or bank loans and to future government administrations),
local governments are not necessarily responsible for any
investment loss. So, they have an extremely strong tendency to
over-spending in order to win out in the keen inter-city
competition.

Simple economic measures, like higher interest rates, can hardly curtail local investment booms because if the investments are driven by a local politicians’ strong desire to achieve headline economic growth and career advancement, higher costs of capital are unlikely to do the trick before the government budget 
is totally hardened ( $\mathrm{Xu}, 2004)$. No wonder a government official in Shanghai laments that, "massive infrastructure-led urban growth has caused a false impression of local prosperity; in fact, most of these new physical configurations are sustained by huge government debts'. ${ }^{7}$ It may be difficult to verify the statement, but at least by taking all the evidences together it seems that under many circumstances, new strategies and competitiveness building are financial liabilities, and may divert public resources to face-lifting projects.

\section{Guangzhou rationale: city repositioning under intensive competition}

Guangzhou city presents an excellent opportunity to examine these issues of local government power and soft budget constraints in competitiveness building. Since the mid-1990s, the city has launched a series of repositioning strategies to revitalize its leading role in the Pearl River Delta (PRD), where perhaps the most intensive inter-city competition in China can be found (Figure 1). ${ }^{8}$ To most people in Guangzhou, the idea of devising pro-growth strategies and developing large projects for building competition can be perfectly justified. ${ }^{9}$ This is a city that once had a leading role in China, but is now consistently overshadowed by other hub cities, as exemplified by the gradually fading away of its role as southern gateway of China in history $(\mathrm{Xu}, 1985)$. This is a city with a glorified commercial tradition distinct from the rest of the country in its pioneering ability to exploit the new scope offered by the reform era (Xu and Yeh, 2003). This is a city wracked by the pain of urban disorders as revealed in the overburdened traffic (Xu and Yeh, 2003), in juxtaposition of many different activities and congestive high density development (Xu, 1985). This is a city plagued by the continuing ravages of government financial scandals, as embodied in the case of Guangzhou ITIC, as well as the subway project (Sina News, 2004b). Finally, this is a city with a palpable inequality, where many (e.g. migrant workers) are still fighting to make ends meet (e.g. employment and housing) (Fan, 2001; Chan, et al., 2003). The idea of large projects to achieve headline economic growth and to build up city image and competitiveness appears logical but questionable. It is for these reasons that the Guangzhou case is fascinating and worthy of further examination. However, it should be noted that despite the important insights in understating the widespread existence of 'debt-burdened' cities in China, it may not 
be sufficient to support a generalized conclusion. More case studies need to be carried out in the future to further examine the arguments in this paper.

\section{[Figure 1 about here]}

Development pressure: inter-city competition in regional development Guangzhou $^{10}$ is one of the oldest cities in southern China, with a long history of more than 2,100 years. Because of its location at the northern tip of the PRD, Guangzhou possessed exceptional conditions as a port, and was nicknamed the "southern gate of China” (Xu, 1985). However, with competition from other port cities (e.g. Shanghai and Hong Kong), Guangzhou later declined to a port of second-rank importance. Its status as a trade and commercial hub was further weakened during the period from 1949 to 1978 because of its geographic location at the coastal "front line", having a very low priority in receiving state investment. The major breakthrough of urban development in Guangzhou came in 1979, following the nation's new economic reform and “open door” policies, which placed Guangzhou in the vanguard of reform. The new status offered an exceptional opportunity for the city to revitalize its former role as a commercial centre and trading port. In particular, land and housing reform (Yeh and Wu, 1996) since the late 1980s has led Guangzhou into a dramatic period of urban development. With the backing of rapid development of industrial and service activities, the city soon enhanced its role as a commercial and business centre in the region (Lin, 2004). To keep up with development, the city built a number of major ring roads, highways, and railways surrounding and radiating from the city to provide easy access to nearby cities and distant provinces (GUPB, 2002). Guangzhou's role as a transportation hub was thus affirmed (Xu and Yeh, 2003).

Notwithstanding its well-established status as the commercial, business, and administrative centre of southern China, Guangzhou has been facing increasing competition from nearby cities in the PRD, where the global shift of capital has brought about a new geography of centres and margins, with former periphery or rural areas having developed into active economic centres in their own right (Sit and Yang, 1997; Lin, 1997, 2004). To complicate this state of affairs, the return of the sovereignty of Hong Kong and Macao significantly challenges Guangzhou's dominance. The central role of Guangzhou has been undermined, as shown by 
indicators like its GDP share in the province, GDP per capita, export, as well as economic growth rate (Table 1). Worse still, the manufacturing industry of Guangzhou is overshadowed by that of cities like Shenzhen and Foshan (Zhang and Liu, 1998). Its conventional strength in service is also outshined by Hong Kong, the regional producer service centre (Yeh, 2003), and is increasingly being challenged by Shenzhen, which is right next to Hong Kong. Outside the PRD, Shanghai is perhaps the strongest competitor. With a tremendous effort in remaking the city as a world city (Wu, 2000a, 2000b), Shanghai has become an important economic and business centre in China, competing fiercely with cities in the PRD region in snatching investment and human capital (Yeh, 1996, 2001). Moreover, Shanghai's dominance is still strong in the Yangtze River Delta, whereas the role of Guangzhou in the PRD is under severe challenge (Table 2). Guangzhou has also experienced a drop in national industrial ranking, from second place next only to Shanghai, to fourth or fifth after Suzhou, a rapidly developing industrial city in the Yangtze Delta (Mingpao, 2003b).

\section{[Table $1 \& 2$ about here]}

Urban problems have also contributed to the declining competitiveness of the city (Guangzhou Daily, 2002). Guangzhou's growth is hindered by limited land resources (Xu and Yeh, 2003). This has forced the government to continuously develop the inner city. A direct outcome is intensive land development, leading to extremely high density-mixed land use, over-burdened traffic and infrastructure facilities (Gaubatz, 1999), and failures of planning control (Xu and Ng, 1998; Xu, 2001). To relieve the traffic congestion, more elevated roads and flyovers have been built in the already-congested inner city. Such a type and scale of development has led to the degradation of the living environment. The problem has been worsened by widespread illegal development and the notorious lack of landscape, green belts, recreation facilities, and other open spaces (Xu and Ng, 1998; Xu, 2001).

New development strategies: Repositioning of the city towards a regional centre Guangzhou residents were discontent about the city’s development. A 1997 opinion poll showed that $73 \%$ of the residents were dissatisfied with Guangzhou's built environment (Wu and Liu, 2002: 28). The disarray of Guangzhou contrasted dramatically with the new progress made in Shanghai and Shenzhen (Yeh, 1996, 
2001; Wu, 2000a, 2000b; Ng, 2004). Guangzhou might lose out to these cities unless immediate actions are taken to re-build its image. Evidences seem to reveal a degree of local support for this mindset (Wu and Liu, 2002). As the Party Secretary of Guangzhou, Mr. LIN Shusen said, "It is a really risky [time] for Guangzhou; since the city has long been proud of being the central city for more than two thousand years; if this status disappeared, Guangzhou would be doomed eternally” (Guangzhou Daily, 2002).

Since the late 1990s, the Guangzhou Government has taken three important steps to rectify its problems, trying to regain the city's status as a regional centre. In the first place, Guangzhou has re-defined its strategic objective, which states that the city would be developed into a, "Regional centre in the world with a high level of prosperity, efficiency and civilization” (GUPB, 2002). This is justified by the statement that,

Every aspect of development should contribute to the upliftment and quality of life of the people... but this is not the sole aim, since the core element of new strategies should help in the process of economic restructuring...to address issues created by declining role of Guangzhou (Nanfang Daily, 2002).

Guangzhou would thus become a liveable ecological city, providing a 'business friendly environment’ (GUPB, 2002).

Secondly, to realize this objective, the government initiated a three-phased urban development strategy of, "minor change in a year, medium change in three, and major change in 2010.” This movement was started in 1998 with the purpose to promote the "greenness, amenity and attractiveness" of the city by embarking on a large number of face-lifting and infrastructure projects to wipe out illegal developments, renovate dilapidated streets and buildings, clean the environment, increase accessibility, and provide open space (Wu and Liu, 2002). The first phase, “minor change in a year (1998-1999)”, was initiated based on 109 image-improving projects (Shi, 2002: 59). This was taken further by the second phase, “medium change in three years (1999 to 2002)," which was mainly implemented through 74 major projects to improve the city's transportation network and eliminate illegal 
constructions (Guangzhou Government, 2001). In total, the city government invested more than US\$8 billion for urban construction from 1999 to 2002 (Editor of Human Habitation, 2002: 9). The first two phases of the strategy have in fact made a difference in the restructuring of the city. Guangzhou won the 2002 Dubai International Award for Best Practices in Improving the Living Environment. 96\% of local residents were satisfied with the city's new development, a big jump over the results as revealed in the same opinion poll in 1997 (Wu and Liu, 2002: 28). The poll results have been extensively publicized by the government to an extent that one has the impression that the poll is being used to mobilize support and engender pubic consensus, and then legitimize the massive public spending yet to come.

In 2002 the third phase of the new development strategy, "major change in 2010," started with the vision of developing the city into a liveable metropolis. In order to achieve this, the government pledged to invest US\$9.67 billion over the next five years (Guangzhou News Net, 2002). A number of large property projects have been initiated or are under way to provide the focus of the city's pro-growth strategies. ${ }^{11}$ These include large transportation projects such as the US\$2.4 billion New Baiyun International Airport, the US\$1.6 billion Nansha Deep Water Port's two 50,000 ton-class berths (first phase), and the US\$3.24 billion Guangzhou MTR (lines 2 \& 3). It also includes fancy face-lifting projects such as the US\$500 million (land price not included) International Convention \& Exhibition Centre, the US\$123 million Grand Opera House, the $228 \mathrm{~km}^{2}$ New City Centre, the US\$1.21 billion International Bio-island, and the $43.3 \mathrm{~km}^{2}$ Guangzhou University Town (Figure 2). Other image improving efforts comprise the building of the US\$484 million Newspaper Cultural Plaza, the US\$157 million New Gymnasium, and the US\$149 million Olympics Sports Centre. In order to get international recognition quickly, many of these projects were simply branded by the world's top architects and planners, and the Guangzhou Government made full use of these architects' 'signatures' to achieve broader urban significance. For example, the new airport was designed by American Parsons, the convention centre by LMN Architects, the new gymnasium by French Paul Andreu Architect, and the Olympics centre by American NEB. A celebrated example of hosting mega-events is the Guangzhou Trade fair. Without exception, all of these projects were initiated by the Guangzhou Government. Take the Nansha Deep Water Port as an example. Nansha is not the most desirable 
site for building a deep-water port because of sea sedimentation. The building of the port was originally envisioned by the mayor of Guangzhou for the purpose of competing with the fast-growing Yantian Port in Shenzhen. ${ }^{12}$

\section{[Figure 2 about here]}

The third, but not least, step taken by the Guangzhou Government was to redraw its administrative boundary by adjusting Huadu and Panyu from the status of county-level cities to districts. ${ }^{13}$ Following the reorganization, the area under the direct administration of the city government was increased from 1,400 $\mathrm{km}^{2}$ to 3,719 $\mathrm{km}^{2}$ (Xu and Yeh, 2003), which enriched the local land bank and alleviated development pressure within the congested city proper (GUPB, 2002). After this, Guangzhou took the initiative to prepare a new Concept Plan, which highlighted the city's new development goals, spatial structure, population, and transportation. Its purpose was to build Guangzhou into a regional centre and a producer service centre with the development of finance, science and technology, information, trade and commerce, transportation, culture, and tourism. ${ }^{14}$ These strategies are legitimized by the local authority in terms of increasing competition and revitalizing the central role of Guangzhou - a view frequently articulated by the mayor and local public agencies (e.g. GUPB, 2002; Guangzhou Daily, 2002; Mingpao, 2003a).

There is no question that competition was the key part of the rationale and ideology for the new strategies. But rationales can also be an excuse for other objectives, which remain more or less hidden in the face of competitive rhetoric. Guangzhou's massive fixed-asset investment is only a small part of the wider response to the worldwide economic slowdown after the 1997 Asian Financial Crisis, which caused difficulty in sustaining an export-led growth in many Chinese cities (Zhao, 2002b). In response, there has been a shift in the government's strategy, from export-led industrialization (which focuses attention on promoting exportation to sustain high growth rate) to strategies that are geared to promote domestic demand through public investment. Government spending has thus become the engine of growth (Xu, 2004). Wu and Liu (2002:35) argue that it is Guangzhou's fixed-asset investment, especially investment in urban construction, which has contributed 
greatly to the city’s GDP performance. This is why Guangzhou can remain among the top three cities in China in terms of economic strength.

\section{Urban outcome}

Building city image and luring investment: success or failure?

The perceived success of new development strategies in rebuilding a city's image has been widely acclaimed by the local and national media and some academic commentators (Xu and Yeh, 2003; Pan et al, 2004). One commentator claimed that the transformation of Guangzhou's image in just a few years, from a cluttered-marketlike city to a community that re-gained its former eminence as the 'flower city', is a remarkable story of local government commitment and public support (Wu and Liu, 2002). The citizens are benefiting from the improvements in traffic, landscape, and living environment. Prior to 1999, for example, of all the daunting challenges the city faced, perhaps none was more pressing than the urgent need to enhance the mobility of citizens. At the time, traffic congestion was so bad that vehicles could only move at a speed of $10 \mathrm{~km} / \mathrm{hr}$ (Wu and Liu, 2002). Now, with large investment in road construction, mobility has been greatly improved, and vehicles can run as fast as 50 $\mathrm{km} / \mathrm{hr}$ in the inner city ( $\mathrm{Wu}$ and Liu, 2002: 27). The opinion poll in Guangzhou reverted from $73 \%$ of the residents who were dissatisfied with Guangzhou's built environment in 1997, to 96\% who were satisfied with the city’s new development in 2003. In the 2001 International 'Garden City’ Contest, Guangzhou won third place in Group E, with a population above one million, and was awarded the title of international 'garden city'.

Another concern is whether the promotion of these strategies can succeed in attracting a large quantity of mobile capital. The government claims that the accumulated sum of foreign capital from 1997 to 2002 represented $61.51 \%$ of the total since the economic reform, and that 115 transnational corporations among the world's top 500 have built branches in Guangzhou (GOCN, 2003a; Guangzhou Government Press Conference, 2004). The city also shows sign of success in transforming the economy. For example, it has become one of three major convention and exhibition centers in China, together with Shanghai and Beijing. However, it will take more time to see the long term effects in attracting investment. 
Soft budget constrain in developing large projects and the validity of these projects

Budgetary revenue, extra-budgetary revenue, and loans constitute three basic sources of government spending in Guangzhou (Shen, 1999). ${ }^{15}$ The former two cannot provide sufficient capital for large projects like the Guangzhou Subway (Sina News, 2004b). In securing finance, the city has to utilize a number of agencies such as the Guangzhou International Trust and Investment Corporation (GZITIC) and the Guangzhou Construction Investment and Development Corporation (GZCIDC), two important borrowing arms of the city government. They are entrusted and appointed by the government to undertake functions like investing, fund-raising, and managing state-owned property within a certain degree of discretion (Shen, 1999; 21st Century Business Herald, 2003). The chain of control from the central government is weak. Therefore, through setting up these investment arms under its auspice, the city government has obtained substantial discretionary power in collecting funds. But what is the validity of investing large projects in this way? How has it softened the budget constraint of the city government in large-scale investment?

Take the GZITIC as an example. GZITIC was set up in 1985 to imitate the China ITIC, the first and biggest of such vehicles in China. Originally, it was established by the city government to fund long-term development for infrastructure projects such as industries, roads, power plants, housing properties, and tourism (Guangzhou Government, 2004). At that time, foreign bankers were not allowed to lend directly to mainland companies, and lending by China's state banks was restricted to state enterprises (Emerging Market, 1999). GZITIC had foreign exchange certificates approved by China's central bank, the People's Bank of China (PBOC), and the State Administration of Foreign Exchange (SAFE) (Guangzhou Government, 2004). This was the only way to invest. With the backing of the city government, GZITIC was able to diversify into more than 20 subsidiaries, including securities brokerages, international trade, hotels, other property investment, as well as joint ventures with local companies that had a government background (21st Century Business Herald, 2003; Guangzhou Government, 2004). Furthermore, despite not being licensed as a commercial bank, GZITIC also took deposits from local depositors by offering high interest rates above the legal rate set by the central bank (Xie, 2000). Without effective legal and financial limitation, GZITIC was used extensively by the Guangzhou Government as a borrowing arm to finance 
government projects. Against US\$726 million (6 billion RMB) in assets, the firm holds liabilities to foreign banks and creditors exceeding US\$1 billion, with a further US\$1.71 billion in domestic liabilities, owed to more than 200 banks and creditors (21st Century Business Herald, 2003). The overseas creditors mainly come from Hong Kong, with the Guangzhou Government and Guangzhou SAFE serving as two guarantees (Xie, 2000). To keep the ailing GZITIC afloat, Guangzhou was allowed to bail out the firm by injecting blue-chip properties and spending US\$362 million from public funding to pay its hard-currency liabilities (21st Century Business Herald, 2003). Part of the bail-out fund came from the central government in the form of loans. Some argued that the strategy of Guangzhou, in paying its debt, was to get new loans to pay current creditors (Sina News, 2004c). GZITIC was opaque to the domestic and overseas banks and investors, who lent it money; the Guangzhou Government, who owned it; the central authority, who was supposed to regulate it; and even to the general public, who contributed to it as depositors. A massive amount of money was lost through bad investment, mismanagement, and even theft (Xie, 2002). In the heightened pressure of financial distress, one deputy mayor went to Hong Kong and explained to creditors that the Guangzhou Government could not make re-payment for GZITIC because the latter was an independent firm bearing its own debts. But on the same day, another deputy mayor hosted a meeting in Guangzhou discussing how to reconfigure GZITIC’s structure (Xu, 2004).

In addition to uncontrollable government spending, unlawful land requisition, and land disputes, large projects were not uncommon. An example is the prominent Guangzhou University Town. It is an ongoing US\$1.44 billion (12 billion RMB) project, covering $43.4 \mathrm{~km}^{2}$ with the claimed purpose to become the largest project of its kind in China in order to promote education and attract more talented people (GUPB, 2002). The Town is situated in Xiaoguwei, which is a fertile farmland region where the natural environment and ancient relics remain well preserved. To bypass the central authority, the Guangzhou government decided to subdivide the area into 39 pieces, and sent land requisition applications of each piece to the provincial government for approval (Sina News, 2004a). ${ }^{16}$ The possibly unlawful pursuit of University Town is a response to a national fever of university town construction, which has sparked concern about the validity and effect of hasty large projects that cause financial crisis and social problems (Market Daily, 2004). The blind 
development of university towns, such as those in Zhuhai and Hangzhou, could mean unhealthy land abuse (Mingpao, 2005). It is most likely that the Guangzhou government and developers used the project as a cover for boosting economic growth and developing commercial facilities, since it is usually easier to justify and get approval for education-related projects (Market Daily, 2004). On top of this, land can be bought at lower prices in this way (e.g. Mingpao, 2005).

Who have actually benefited from this project? As far as the city government is concerned, the project has boosted local esteem and promoted GDP growth, as well as advanced local politicians' careers (China Information Centre, 2004). To requisition land, the city government paid US\$5,430-9,075 per ha (30,000 to 50,000 RMB per mu) to displaced farmers (Market Daily, 2004). In 2003, three pieces of land were leased to commercial developers with auction price as high as US\$4.5-9.1 million per ha (2.5-5 million RMB per mu) (Sina News, 2004a). For universities (developers in this case) that will move to the University Town, the government has decided on US\$1.45 billion (12 billion RMB) in discount loans (mostly bank loans), and universities will pay the principal, while the government provides free land and pays the interests as subsidies (GOCN, 2003b). Clearly, this large project entails massive financial cost, which has been at least partially underwritten by the public sector. For commercial and other land developers, the project is also good news since the city government has to rely on their investment to build ancillary facilities and properties (e.g. supermarket, hotels, and office buildings) (Market Daily, 2004). For residents of the Xiaoguwei district, where the University Town is located, the project means more disturbances than benefits. More than 10,000 farmers were dislocated (Sina News, 2004a), while the remaining farmers grieve the ecological loss the project has caused (Market Daily, 2004). A group of residents have filed a lawsuit against the city government after being forced to move from their legal properties, which were built with government-approved land use permits in 1994 (Sina News, 2004a).

Large projects often divert scare public sector resources away from 'basic' services that the city's disadvantaged groups are particularly dependent upon. This is exemplified by the US\$109 million Guangzhou Pension Fund (Ju, 2004) and the US\$18 million Local Education Fund (Dayang News, 2003) that were diverted by public agencies to develop large property projects, or deposited in GZITIC to generate 
high interest rates. Another example is the controversy about the Guangzhou Opera House. The government claims the opera house will be a new expressive icon that integrates with urban strategy to create new cultural significance to the city. Delegates of the local People's Congress question this expensive and hasty project, and call a halt to it because it would further divert resources away from hard-pressed local services, such as rebuilding deprived neighbourhood schools in the inner city. The government has ignored this school problem for a long time due to the claim of lack of funding (Yangcheng Daily, 2000). This diversion of capital will have a disproportionate long-term impact upon the disadvantaged in the city.

\section{Conclusion}

Since the 1980s, Chinese cities have seen increased competition for mobile capital. This is built upon the foundation of an open door policy that allows foreign participation in urban development. With great reduction in funding from the central government, localities now have to go outside formal state channels to raise funds in many forms. In particular, overseas capital has become an important form of investment in promoting local growth. To attract overseas investors (e.g. multinational enterprises), which are highly mobile in considering the locations of their plants and offices, cities increasingly have to take on an 'entrepreneurial' stance in promoting growth and marketing themselves, and to compete with other localities in attracting capital in promoting economic development. As such, they are under increasing pressure to initiate physical change and to create 'resources' to make cities more attractive to investors. This has led to the creation of league tables of city's competitiveness, in which rankings are determined by single or multiple variables related to capital and resources. These resources are further defined in relation to infrastructure development, institutional set-up, social and cultural amenities, and physical attractiveness, which are all so easy to imitate. Thus, competition has to be about the differences in image (Zhai et. al, 2004). The fear of diminishing importance and declining rank of cities in regional development intensifies the competition for mobile capital and image re-construction that are believed to have considerable economic multiplier effects. Economic reforms (e.g. financial and land reform) enable local state in China to find funding to fund mega-infrastructure projects to build the competitiveness of the city, because these reforms allow greater ability of local state 
in financing and land disposal. With two critical resources (capital and land) that are more easily available to localities than before, the idea of harnessing large projects to a broad urban agenda is becoming extremely popular in Chinese cities. Local governments have adopted pro-growth strategies, focused on large projects as a means of promoting economic development and projecting new and dynamic city images to promote competitiveness.

Adding to the tempestuous upsurge of competitiveness building, government officials, especially mayors, are also stimulated to develop large projects for their own career advancement. They are appointed cadres who are assessed for promotion on the basis of political loyalty and 'merit-based' factors, as indicated by economic performance and 'achievement in office'. The physical form of a built environment such as city square, a fly over area, metro-mass-transit, and a development zone, by their nature, is easier to use in visualizing achievement than 'intangible' social development ( $\mathrm{Wu}, 2005)$. The pursuit of physical transformation is also highly facilitated by the 'soft budget constraint syndrome' of local state in urban development. Any loss-making investment is not a matter of life and death. A debtburdened city never leads to bankruptcy or an end of the office term of key cadres. Rather, debt may be helpful for these cadres in climbing up the political ladder. During his term in office from 1993-2001, Mr. BO Xilai, the former mayor of Dalian in the Liaoning Province, transformed Dalian from a pollution-plagued city to one that has been highly acclaimed by local residents. Its broad boulevards are lined with trees, manicured gardens, squares, and parks. Traffic flows smoothly. Dust levels are low despite considerable construction work. But beneath the astonishing transformation is the debt-burdened local finance. ${ }^{17}$ For example, Dalian ITIC defaulted on US\$140 million in foreign debt. But Mr. Bo has been largely untainted by the ITIC failure. He was appointed as Deputy Governor and Acting Governor of the Liaoning Province in January 2001. In February of the same year, he became the Governor of the Liaoning Province. In February 2004, he was further appointed the Minister of Commerce, and has held the position since.

China is by no means a 'ruled by law' society. Local cadres are not elected officials, like their counterparts in many countries in the West. Empowered local state can lead to unscrupulous local officials running the city administration. In building 
competitiveness, such operations of the state may involve activities more fundamental than 'using preferential taxes and providing subsidies' to compete with one another and to attract and retain businesses. The local state can go beyond its legal and budgetary constraints, as well as market logic to recklessly mobilize resources. This defines one fundamental parameter of local state in China, and helps us to re-think two important issues in current theoretical debates. The first issue is about urban entrepreneurialism in China. With a local state not considering 'market logic', it is questionable to say that the state is 'entrepreneurial' in nature. The second issue relates to the role of the state, as compared with those in the coalition politics described by theories (e.g. growth machine) originating in some Western countries. Chinese states, as market players and regulators, have more complicated ultimate goals than 'growth'. 'Growth' might sometimes be rhetoric - an excuse for other hidden agendas at the expense of true growth impetus in a city in the long run. Moreover, Chinese society is far from being pluralist. Despite the widespread encouragement of public-private partnership and the participation of external (nonpublic) capital in local growth, urban development is by no means a process that can be led by non-state developers. Since the state holds two critical resources, capital and land, large-scale urban projects such as civic centres, concert halls, industrial parks, and mass-transit systems are most likely instigated by the state. To initiate or coordinate these projects is a complicated 'social engineering' project (Wu, 2002). These projects, by their nature, are concerned with the recreation and reconfiguration of space. Furthermore, the processes involved, such as acquisition of collective farmland, arrangement of relocated residents, and usage of credits for getting loans, requires the input of local governments who tend to replace the market and monopolize political and social resources that are not available to other market actors (Wu, 2005). Thus, the role of the 'appointed' local state in China is different from those 'elected' states in advanced capitalism, which often seek 'growth' in the context of coalition politics that operate in highly pluralist societies with strong social mobility power.

The outcome of competitiveness building in Chinese cities can be twofold. On the one hand, competitive strategies present the opportunity for a locality to strengthen its competition and attractiveness among cities. The Guangzhou case shows that how much these strategies actually stimulate business and lure investment 
in the long term has yet to be seen. The citizens at large are immediately and directly benefiting from the improved living environment, and thus these projects have gained much popularity and support. There are also signs of success of Guangzhou in transforming the economy. But whether or not the initial success of these 'repositioning strategies' can continue is still a difficult question to answer, because Guangzhou is not the only city in China trying to build a world-class city with international standards. Eighty-six Chinese cities have formulated plans to develop themselves into "international metropolitan cities” (People, 2002). Infrastructure-led development can be found in cities within the Pearl River Delta, such as Hong Kong, Shenzhen, Foshan, and Dongguan, and in cities in other parts of China such as Beijing, Shanghai, and Chongqing. In addition to big cities, small cities and towns in China, especially those in the booming eastern coastal provinces, are also keen in competitiveness building. This is understandable, because every locality knows the importance of increasing its competitiveness in order to attract footloose investment and to face increasing competition within China as well as from abroad.

On the other hand, 'competitiveness building' in Chinese cities creates externalities. Perhaps the most critical one of these is the validity of a local state's approach to building competitiveness and subsequent urban outcomes. Problems such as 'debt-burdened' local finance, the miseries of dislocated farmers and residents, and the misuse of public resources are not as visible as a city's physical transformation. Government officials are not assessed based on these criteria. Moreover, the ability of the local state in fund-raising for large projects is now mainly built upon the 'soft budget constraint' syndrome. To a large extent, these projects are not the outcomes of entrepreneurial governance, but big gambles that may succeed or fail. Take Shanghai and Zhuhai as examples. In the early development of Pudong in the mid-1990s, there were sceptics on how to fill the massive development (Haila 1999). But now a large percentage of these earlier vacancies are filled because of the economic bloom in Shanghai. It is not so lucky in the case of Zhuhai. Zhuhai also had an ambitious development plan that led to the building of an international airport. But the expected economic development and foreign investment did not come and now the Zhuhai government is in big debt. Competitiveness building and place-making exists in most cities in the world, but the scale and speed of Chinese cities in doing these may be 
unmatched. This will be continued to be the case, given the political economy of the government structure and soft budgeting system in Chinese cities.

Large projects that entail massive financial costs and heighten capital liability will always appear risky, especially when many local governments are debt-burdened per se. This is particularly so given the pressure of funding the debt charges associated with large projects; these have exacerbated the financial crisis faced by local governments (Chang, 2001). From a political economy point of view, large projects are mostly undertaken at the will of local politicians, who know how to take advantage of social inefficiencies (e.g. soft budget constraints), circumventing central regulations while ignoring 'welfare provisions' or other 'basic needs' of the disadvantaged. Harvey (1989) once argued that such projects could be a source of urban instability and malaise, in particular when they are inherently speculative in execution and the risk is to a large extent borne by the 'public'. Inter-city competition might be an excuse for construction and the enhancement of property values, rather than the amelioration of the conditions of the city. Competitiveness building involves primarily two elite groups in Chinese cities: the local government and commercial interests. The local government, especially top government officials, sees the potential for expanding economic growth and opportunities for career advancement. The commercial interests (e.g. financiers) see the opportunities for rent seeking and broadening the material gains through land transformation. Both elites tend to use city physical change, led by land development, to secure their gains through quick and visible actions that may generate considerable public controversy and diverge public spending from basic services for the disadvantaged. As such, the new strategies are not as they are portrayed by their advocates: they are not in the unitary interest of cities, and not everyone gain from enhanced local prosperity.

\section{Footnote:}

* Conversion factor: US\$1= RMB 8.27

[1]. Porter's diamond-model (Porter, 1990) is a model of regional competitiveness. It identifies four geographical development determinants that contribute to regional competitive capabilities: (1) factor (input) conditions; (2) demand conditions; (3) related and supporting industries; and (4) context for firm strategy and rivalry. 
These four determinants mutually reinforce one another and the interactions within a region.

[2]. According to the Budget Law of the People's Republic of China (Article 28), the local budgets at various levels shall be compiled according to the principles of keeping expenditures within the limits of revenues, and maintaining a balance between revenues and expenditures. They shall not contain deficit. The law further stipulates that local governments may not issue local bonds, except as otherwise prescribed by laws or the State Council.

[3]. The Shanghai Government has moved most international flights and logistics facilities from the old Hongqiao Airport to the Pudong Airport, which is very far from the city and regional centre. As a result, firms in nearby cities like Suzhou and Wuxi have to spend one more hour than before to use the Pudong Airport. The decision to move services to the Pudong Airport is a deliberate policy of Shanghai to keep its competitiveness as a regional magnet to attract foreign capital. In the short term, this may make Shanghai more attractive because it is more accessible to critical producer and logistics services. But in the long run, the policy may not boost Shanghai's role as a regional service centre because it has forced nearby cities to review their plans to build their own new airports. (Li, Zhu and Chen, 2003).

[4]. There are ample examples. One author of this paper once worked as a planning consultant for the Yuxi City Government in the Yunnan Province to devise a concept plan for the city. Large infrastructure projects suggested in the final scheme are all originated from the mayor. These include, among others, a new city centre and a fancy concert hall.

[5]. The so called "big four" refers to the Bank of China, the Industrial and Commercial Bank of China, the Construction Bank of China, and the Agricultural Bank of China.

[6]. An example is the recent case of Tieben Steel and Iron Company. With the backing of local governments and state-owned financial institutions, Jiangsu Tieben (in Changzhou) circumvented rules and regulations governing loans and investments. The company had US\$72.55 million (600 million RMB) in registered capital. However, six financial institutions, including three of the big four state commercial banks, enabled it to fund investment projects totaling US $\$ 1.3$ billion (10.6 billion RMB) (Wu, 2004).

[7]. This is from a telephone interview with a government official in Shanghai, in May 2003.

[8]. Five among the top ten most competitive cities in China are located in the Greater Pearl River Delta (PRD) Region, which consists of the PRD in Mainland China, Hong Kong, and Macao (Li, Zhu and Chen, 2003). They are Guangzhou, Shenzhen, Dongguan, Hong Kong, and Macao.

[9]. This is based on a telephone interview with a government official in the Guangzhou Construction Commission, conducted on 7 July 2004. 
[10].For a detailed description on physical and administrative characters of Guangzhou, please refer to Xu and Yeh (2003). Guangzhou, in this study, refers to the whole Guangzhou Municipality, which includes ten city districts and two county-level cities.

[11].For detailed information on these projects, please refer to Xu and Yeh (2003).

[12].From an interview with an official in the Guangzhou Port Authority, in May 2003.

[13]. The redrawn administrative boundary is approved and backed by the central government.

[14].For more information on the new concept plan, please refer to GUPB (2002) and $\mathrm{Xu}$ and Yeh (2003).

[15]. The importance of the non-public sector in urban infrastructure construction has also grown continuously in recent years because more and more functions previously performed by local governments (e.g. water supply and bridges) are now being allocated to non-public investors through transferring development rights and listing companies since the 1990s (Shen, 1999). However, our paper focuses mainly on the leading role of local governments in financing large infrastructure projects.

[16]. According to the Land Administration Act of China, any requisition of Basic Agricultural Land, no matter how small, requires approval by the State Council. Any requisition of other arable land over 35 hectares, or non-arable land over 70 hectares, also needs authorization from the State Council.

[17]. This is based on an interview with a government official from the Ministry of Construction of the People's Republic of China, conducted on 27 November 2005 in Hong Kong. 


\section{Reference:}

Ashworth, G. J. and H. Voogd (1990) Selling the city. Belhaven, London.

Ba, Shusong (2003) Place-making: why selling land is so popular. Zhangjiang Daily 7 August 2003 (in Chinese).

Begg, I. (1999) Cities and competitiveness. Urban Studies 36, 795-809.

Block, F. (1994) The roles of the state in the economy. In N.J. Smelser and R. Swedberg (eds.), The handbook of economic sociology, Princeton University Press, Princeton, NJ.

Cartier, Carolyn (2002), Transnational urbanism in the reform-era Chinese city: landscapes from Shenzhen. Urban Studies 39.9, 1513-32.

Castells, M. and P. Hall (1994) Technopoles of the world: the making of 21st century industrial complexes. Routledge, London.

Chan, R.C.K., Y.M. Yao and S.X.B. Zhao (2003) Self-help housing strategy for temporary population in Guangzhou. Habitat-International 27.1, 19-35.

Chang, G.G. (2001) The coming collapse of China. Random House, New York.

Cheshire, P. (1999) Cities in competition: articulating the gains from integration. Urban Studies 36, 843-64.

China Construction News (2003) China Construction Bank stops approving loans to 'showing off' property projects. 30 May (in Chinese).

China Information Centre (2004) Construction of university towns leads to land enclosure. Available at www.cicus.org/news/, visited on 20 July 2004 (in Chinese).

Cox, K. (1995) Globalisation, competition and the politics of local economic development. Urban Studies 32.2, 213-24.

Dayang News (2003) Guangzhou is difficult to get the 150 million Education Fund back. 30 October. Available at www.dayoo.com/content/2003-10/30/, visited on 21 July 2004 (in Chinese).

Dicken, P. (2003) Global shift: reshaping the global economic map in the 21st century. Guilford Press, London.

Duckett, J. (1998) The entrepreneurial state in China. Routledge, London.

Editor of Human Habitation (2002) Editorial. Human Habitation 2/3, 7-16 (in Chinese).

Emerging Market (1999) Economic effects of legal infrastructure - collapse of the Guangdong international trust and investment corporation. Available at www.xensei.com, visited on 19 July 2004.

Fagerberg, J. (1996) Technology and competitiveness. Oxford Review of Economic Policy 12.3, 39-51. 
Fainstein, S. S. (1994) The city builders: property and planning in London and New York. Blackwell, Oxford.

Fan, C.C. (2001) Migration and labor-market returns in urban China: results from a recent survey in Guangzhou. Environment and Planning A 33.3, 479-508.

Garreau, J. (1991) Edge city: life on the new frontier. Doubleday, New York.

Gaubatz, P. (1999) China's urban transformation: patterns and processes of morphological change in Beijing, Shanghai and Guangzhou. Urban Studies 36.9, 1495-521.

GOCN (Guangdong Overseas Chinese Net) (2003a) The mayor reviews Guangzhou's economy. 12 November. Available at www.gdoverseaschn.com.cn/gdyw, visited on 21 July 2004 (in Chinese).

GOCN (Guangdong Overseas Chinese Net) (2003b) University town Schedule set. Available at www.GOCN.com/english/, visited on 20 July 2004.

Guangzhou Daily (2002) Popular sayings in Guangzhou on urban development. 5 January (in Chinese).

Guangzhou Government (2001) Over 60 roads have improved. Available at www.gznete.com, visited on 6 August 2002 (in Chinese).

Guangzhou Government (2004) Guangzhou investment environment. Available at www.gzscse.gov.cn, visited on 15 July 2004 (in Chinese).

Guangzhou Government Press Conference (2004). Available at www.gz-gov.org/, visited on 22 July 2004 (in Chinese).

Guangzhou News Net (2002) Major change in Guangzhou: 80 billion investments in next five years. 3 December. Available at www.gznet.gov.cn, visited on 2 June 2003 (in Chinese).

Guangzhou Statistics Bureau (various years) Guangzhou statistics yearbook. China Statistics Yearbook Printer, Beijing (in Chinese).

GUPB (Guangzhou Urban Planning Bureau) (2002) Strategic plan for Guangzhou urban development. GUPB, Guangzhou (in Chinese).

Haila, A. (1999) Why is Shanghai building a giant speculative property bubble?. International Journal of Urban and Regional Research 23.3, 583-8.

Harvey, D. (1989) From managerialism to entrepreneurialism: the transformation in urban governance in late capitalism. Geografiska Annaler 71, 3-17.

Herrschel, T. (1998) From socialism to post-fordism: the local state and economic policies in Eastern Germany. In Hall, T. and P. Hubbard (eds.) The entrepreneurial city, John Wiley \& Sons Ltd, Chichester.

Hiller, H. (2000) Mega-events, urban boosterism and growth strategies: an analysis of the objectives and legitimations of the Cape Town 2004 Olympic Bid. International Journal of Urban and Regional Research 24.2, 439-58. 
Holz, C. (1992) The role of central banking in China's economic reforms. East Asia Program, Cornell University, Ithaca.

Hong Kong Commercial Daily (2004) Banks investment failed in Tieben Steel and Iron Company; domestic media points out it is closely related to local government's interference in lending operation. 2 May (in Chinese).

Huang, Shiyuan (1996) Urban competition: rethinking the development strategies in Beijing. Urban Issues 2, 60-5 (in Chinese).

Jessop, B. (1998) The narrative of enterprise and the enterprise of narrative: place marketing and the entrepreneurial city. In Hall, T. and P. Hubbard (eds.), The entrepreneurial city: geographies of politics, regime and representation, John Wiley \& Sons Ltd, West Sussex.

Jing, Jin and Hengfu Zou (2003) Soft-budget constraint on local governments in China. In Jonathan Rodden, Gunnar S. Eskeland and Jennie Litvak (eds.), Fiscal decentralization and the challenge of hard budget constraints, MIT Press, Cambridge, Mass.

$\mathrm{Ju}$, Jin (2004) A true story behind the 890 million pension fund being embezzled. Available at www.comefromchina.com/newbbs/, visited on 21 July 2004 (in Chinese).

Kornai, Janos (1986) The soft budget constraint. Kyklos 39, 3-30.

Kornai, Janos (1992) The socialist system: the political economy of communism. Oxford University Press, Oxford.

Kotler, P., D.H. Haider and I. Rein (1990) Marketing places: attracting investment, industry, and tourism to cities, states, and nations. Free Press, New York.

Kresl, P. and B. Singh (1999) Competitiveness and the urban economy: twenty-four large US metropolitan areas. Urban Studies 36, 1017-27.

Krugman, P. (1996) Making sense of the competitiveness debate. Oxford Review of Economic Policy 12, 483-99.

Li, Wei, Wenyi Zhu and Lei Chen (2003) Reading the competitiveness ranking of Chinese cities. Available at news.soufun.com/2003-08-14/186041.htm (in Chinese).

Lin, G.C.S. (1997) Red capitalism in South China: growth and development of the Pearl River Delta, UBC Press, Vancouver.

Lin, G.C.S. (2004) Toward a post-socialist city? Economic tertiarisation and urban reformation in the Guangzhou Metropolis, China. Eurasian Geography and Economics 45.1, 18-44.

Lo, C.P. (1994) Economic reforms and socialist city structure: a case study of Guangzhou, China. Urban Geography 15.2, 128-49.

Loftman, P. and B. Nevin (1996) Going for growth: prestige projects in three British cities. Urban Studies 33.6, 991-1019. 
Logan, J.R. and H.L. Molotch (1987) Urban fortune: the political economy of place. University of California Press, Berkeley.

Market Daily (2004) News focus: how did the Guangzhou University Town subdivide land plot for illegal land requisition. 2 January (in Chinese).

Mingpao (2003a) Guangzhou deputy mayor: Nansha will become a connecting point in the cooperation of Guangdong, Hong Kong and Macao. 4 February (in Chinese).

Mingpao (2003b) Urban strength: Suzhou surpasses Guangzhou. 12 March (in Chinese).

Mingpao (2005) Illegally approved University Town: Zhuhai Party Secretary punished by the Party Committee. 28 January (in Chinese).

Molotch, H. (1990) Urban deals in comparative perspective. In J.R. Logan and T. Swanstrom (eds.), Beyond the city limits, Temple University Press, Philadelphia.

Nanfang Daily (2002) Guangzhou's changes in medium term and economic development strategies. 19 May (in Chinese).

Nanfeng Windows (2004) Grieve for land in China. Available at www.ziyoulianbang.com/bbs/, visited on 6 May 2004 (in Chinese).

Ng, M.K. (2004) Shenzhen: city profile. Cities 20.6, 429-41.

Ni, Pengfei (2001) A theory and clustering strategy to promote Chinese cities' competitiveness. Available at www.macrochina.com.cn, visited on 28 May 2004 (in Chinese).

Oi, Jean C. (1995) The role of the local state in China's transitional economy. The China Quarterly 144, 1132-49.

Oi, Jean C. (2000) Rural China takes off: institutional foundations of economic reform. NetLibrary, Boulder.

Pan, An, Gaofeng Peng, Yong Chen and Li Jiang (2004) Fully implement new development strategies to promote new urban growth in Guangzhou. City Planning Review 28.2, 25-28 (in Chinese).

Parkinson, M. and A. Harding (1995) European cities toward 2000: entrepreneurialism, competition and social exclusion. In M. Rhodes (ed.), The regions and the new Europe: patterns in core and periphery development, Manchester University Press, Manchester.

People (2002) 86 cities build 'international metropolitan city'. 7 August. Available at www.people.cn/GB/guandian/26/20020807/794161.html, visited on 11 August 2004 (in Chinese).

People's Daily (2004) Construction Bank names IPO underwriters. 15 May. Available at english.peopledaily.com.cn, visited on 30 June 2004.

Porter, M. (1990) The competitive advantage of nations. Macmillan, London. 
Porter, M. (1995) The competitive advantage of the inner city. Harvard Business Review May/June, 55-71.

Porter, M. (1998) On competition. Harvard Business School, Mass.

Scott, A. (1988) New industrial spaces. Pion Limited, London.

Shen, Bainian (1999) To speed up new institutional reform for urban infrastructure investment, operation and management in accordance with demands of market economy. Urban and Rural Construction 8, $24-5$ (in Chinese).

Shi, Hongping (2002) Promote comprehensive environmental improvement scheme to improve city image. Human Habitation 2/3, 58-65 (in Chinese).

Short, J.R., L.M. Benton, W.B. Luce and J. Walton (1993) Reconstructing the image of an industrial city. Annals of the Association of American Geographers 83.2, 207-24.

Sina News (2004a) Behind the displacement of Guangzhou University Town. 25 May. Available at www.sina.com.cn, visited on 25 May 2004 (in Chinese).

Sina News (2004b) Guangzhou MTR has a debt of 7.6 billion, local People's Congress asks for an explanation on pushing the construction of MTR. 14 June. Available at finance.sina.com.cn, visited on 14 June 2004 (in Chinese).

Sina News (2004c) Guangzhou Planning Commission: Guangzhou MTR has 7.6 billion yuan in debt. 21 May. Available at finance.sina.com.cn, visited on 14 June 2004 (in Chinese).

Sing Tao Daily (2004) Central government's arm twisting measures to tackle inflation. 3 May.

Sit, V.F.S. and C. Yang (1997) Foreign-investment-induced exo-urbanization in the Pearl River Delta, China. Urban Studies 34.4, 647-77.

Standard (2004) Spending rife despite cool-it-call. 4 May.

Stoker, G. (1995) Regime theory and urban politics. In D. Judege, G. Stoker and H. Wolman (eds.), Theories of Urban Politics, Sage, London.

Twenty-first Century Business Herald (2003) GZITIC restructuring: background and forefront. 23 May (in Chinese).

Walder, A.G. (1995) Local governments as industrial firms: an organizational analysis of China's transitional economy. American Journal of Sociology 101, 263-301.

Wang, Jici et al. (2001) Innovative spaces: enterprises clusters and regional development. Beijing University Press, Beijing (in Chinese).

Wilson, P.A. (1995) Embracing locality in local economic development. Urban Studies 32: 645-58. 
Wu, F. (1999) The game of landed property production and capital circulation in China's transitional economy, with reference to Shanghai. Environment and Planning A 31, 1757-71.

Wu, F. (2000a) Place promotion in Shanghai, PRC. Cities 17.5, 349-61.

Wu, F. (2000b) The global and local dimensions of place-making: remaking Shanghai as a world city. Urban Studies 37.8, 1359-77.

Wu, F. (2002) China's changing urban governance in the transition towards a more market-oriented economy. Urban Studies 39.7, 1071-93.

Wu, F. (2005) Post reform urban condition in China. Unpublished manuscript.

Wu, Huanqiang and Xi Liu (2002) United strength promote changes in the medium term”. Human Habitation 2/3, 2-37 (in Chinese).

Wu, Zhong (2004) Banks fear lending backlash. Standards. 5 May.

Xie, Ruolan (2000) Lies told by Guangzhou City Government. Available at www.epochtimes.com.hk, visited on 12 July 2004 (in Chinese).

$\mathrm{Xu}$, Jiang (2001) The role of land use planning in the land development process in China: the case of Guangzhou. Third World Planning Review 23.3, 229-48.

Xu, Jiang and Anthony Yeh (2003) City profile: Guangzhou. Cities 20.5, 361-74.

$\mathrm{Xu}$, Jiang and M.K. Ng (1998) Socialist urban planning in transition: the case study of Guangzhou, China. Third World Planning Review 20.1, 35-51.

$\mathrm{Xu}$, Kangning (2001) Top ten cities in the ranking of city competitiveness. Economic Daily. October 18 (in Chinese).

$\mathrm{Xu}$, Steven (2004) Why higher interest rates aren't the answer. South China Morning Post. 6 May.

Xu, Xueqiang (1985) Guangzhou: China's Southern Gateway. In V.F.S. Sit (ed.), Chinese cities: the growth of the metropolis since 1949, Oxford University Press, Hong Kong.

Yangcheng Daily (2000) Motion to call a halt to the Guangzhou Opera House by the delegates of People's Congress. 8 April. Available at www.linkhold.com, visited on 22 July 2004 (in Chinese).

Ye, Yan (2001) Examining projects showing off political achievement. Available at www.luckup.net, visited on 25 June 2004 (in Chinese).

Yeh, A.G.O. (1985) Physical planning of Shenzhen Special Economic Zone. In K.Y. Wong and D.K.Y. Chu (eds.), Modernization in China: the case of the Shenzhen Special Economic Zone, Oxford University Press, Hong Kong.

Yeh, A.G.O. (1996) Pudong - remaking Shanghai as a world city. In Y.M. Yeung and Y.W. Sung (eds.), Shanghai: transformation and modernization under China's open policy, The Chinese University Press, Hong Kong.

Yeh, A.G.O. (2001) Hong Kong and the Pearl River Delta: competition or cooperation?. Built Environment 27.2, 129-45. 
Yeh, A.G.O. (2003) Hong Kong-Pearl River Delta producer service linkage. In Guanghan Chen, Yunyuan Zhou, A.G.O. Yeh and V.F.S. Sit (eds.), Promote global competitiveness of Greater Pearl River Delta, Sun Yat-sen University Press, Guangzhou (in Chinese).

Yeh, A.G.O. and Fulong Wu (1995) Internal structure of Chinese cities in the midst of economic reform. Urban Geography 16.6, 521-54.

Yeh, A.G.O. and Xia Li (1999) Economic development and agricultural land loss in the Pearl River Delta, China. Habitat International 23.3, 373-90.

Young, C. and S. Kaczmarek (1999) Changing the perception of the post-socialist city: place promotion and imagery in Lodz, Poland. The Geographical Journal 165, 183-91.

Zhai, Baohui, Yuliang Jia and Qingyun Xu (2004) A long way to go: the coordinative development in the capital region of China?. Available at www.isocarp.org/Data/case_studies/434.pdf, visited on 31 January 2005.

Zhang, Le-yin (1999) Chinese central-provincial fiscal relationship, budgetary decline and the impact of the 1994 fiscal reform: an evaluation. The China Quarterly $157,115-41$.

Zhao, Yanjing (2002a) From urban administration towards urban management. City Planning Review 26.11, 7-15 (in Chinese).

Zhao, Yanjing (2002b) The situation and the judgment of the urban development in China. City Planning Review 26.3, 8-17 (in Chinese).

Zhao, Yanjing and Zhijian Zhang (2002) On fund raising for urban development. Planners 12, 70-74 (in Chinese).

Zhu, Jieming (2004) Local developmental state and order in China's urban development during transition. International Journal of Urban and Regional Research 28.2, 424-47. 


\section{List of Tables}

Table 1 - The declining role of Guangzhou in the rapidly developing Pearl River Delta region

Table 2- Guangzhou and Shanghai: a comparison of their role in the regional economy (with selected cities)

Figure 1: Guangzhou in the competitive Greater Pearl River Delta Region

Figure 2: Ten major infrastructure projects of Guangzhou 
Table 1: The declining role of Guangzhou in the rapidly developing Pearl River Delta region

\begin{tabular}{|c|c|c|c|c|c|c|c|c|c|}
\hline & Years & \begin{tabular}{|c|} 
Land area \\
$\left(\mathrm{km}^{2}\right)$
\end{tabular} & $\begin{array}{c}\% \text { in } \\
\text { PRD's } \\
\text { total } \\
\end{array}$ & $\begin{array}{c}\text { Registered } \\
\text { Population } \\
\text { (million) }\end{array}$ & $\begin{array}{c}\text { \% in PRD's } \\
\text { total }\end{array}$ & $\begin{array}{l}\text { GDP (US\$ } \\
\text { billion)* }\end{array}$ & \begin{tabular}{|c|}
$\%$ in \\
PRD's total
\end{tabular} & $\begin{array}{c}\text { GDP } \\
\text { growth } \\
\text { rate (\%) } \\
\end{array}$ & $\begin{array}{c}\text { Expor1 } \\
\text { (US\$ } \\
\text { billion) } \\
\end{array}$ \\
\hline \multirow[t]{3}{*}{ Pearl River Delta } & 1990 & 41,698 & $100.0 \%$ & 19.3 & $100.0 \%$ & 10.54 & $100 \%$ & 17.8 & \\
\hline & 1995 & 41,698 & $100.0 \%$ & 21.4 & $100.0 \%$ & 47.16 & $100 \%$ & 20.3 & \\
\hline & 2001 & 41,698 & $100.0 \%$ & 23.4 & $100.0 \%$ & 101.14 & $100 \%$ & 12.7 & \\
\hline \multirow[t]{3}{*}{ Guangzhou } & 1990 & 7,434 & $17.8 \%$ & 5.9 & $30.6 \%$ & 3.87 & $37 \%$ & 14.2 & \\
\hline & 1995 & 7,434 & $17.8 \%$ & 6.4 & $29.9 \%$ & 15.03 & $32 \%$ & 16.4 & \\
\hline & 2001 & 7,434 & $17.8 \%$ & 7.1 & $30.3 \%$ & 32.48 & $32 \%$ & 12.7 & \\
\hline \multirow[t]{3}{*}{ Shenzhen } & 1990 & 1,949 & $4.7 \%$ & 2.0 & $10.4 \%$ & 2.08 & $20 \%$ & 38.1 & \\
\hline & 1995 & 1,949 & $4.7 \%$ & 3.5 & $16.4 \%$ & 9.63 & $20 \%$ & 23.0 & \\
\hline & 2001 & 1,949 & $4.7 \%$ & 4.7 & $20.1 \%$ & 23.63 & $23 \%$ & 13.2 & \\
\hline \multirow[t]{3}{*}{ Zhuhai } & 1990 & 1,457 & $3.5 \%$ & 0.8 & $4.1 \%$ & 0.50 & $5 \%$ & 24.7 & \\
\hline & 1995 & 1,457 & $3.5 \%$ & 1.1 & $5.1 \%$ & 2.24 & $5 \%$ & 16.3 & \\
\hline & 2001 & 1,457 & $3.5 \%$ & 1.3 & $5.6 \%$ & 4.43 & $4 \%$ & 12.1 & \\
\hline \multirow[t]{3}{*}{ Dongguan } & 1990 & 2,465 & $5.9 \%$ & 1.3 & $6.7 \%$ & 0.79 & $7 \%$ & 17.8 & \\
\hline & 1995 & 2,465 & $5.9 \%$ & 1.4 & $6.5 \%$ & 2.49 & $5 \%$ & 25.3 & \\
\hline & 2001 & 2,465 & $5.9 \%$ & 1.5 & $6.4 \%$ & 7.00 & $7 \%$ & 18.0 & \\
\hline \multirow[t]{3}{*}{ Foshan } & 1990 & 3,865 & $9.3 \%$ & 2.8 & $14.5 \%$ & 1.51 & $14 \%$ & 22.0 & \\
\hline & 1995 & 3,865 & $9.3 \%$ & 3.4 & $14.5 \%$ & 5.27 & $11 \%$ & 22.0 & \\
\hline & 2001 & 3,865 & $9.3 \%$ & 3.4 & $14.5 \%$ & 12.91 & $13 \%$ & 11.1 & \\
\hline
\end{tabular}

Note: GDP growth rate in 1990 for all geographic units are average figures for the period 1981 to 1994 Sources: Guangdong Statistics Bureau (various years). 
Table 2: Guangzhou and Shanghai: a comparison of their role in the regional economy (with selected cities)

Guangzhou in the Pearl River Delta (PRD) 2001

\begin{tabular}{|c|c|c|c|c|c|c|c|}
\hline & $\begin{array}{c}\text { Guangzhou } \\
\text { (GZ) }\end{array}$ & PRD & $\begin{array}{l}\% \text { of } G Z \\
\text { in PRD }\end{array}$ & Shenzhen & Zhongshan & Dongguan & Foshan \\
\hline Land area $\left(\mathrm{km}^{2}\right)$ & 7,434 & 41,698 & $17.8 \%$ & 1,949 & 1,800 & 2,465 & 3,914 \\
\hline $\begin{array}{l}\text { Registered Pop. } \\
\text { (million) }\end{array}$ & 7.13 & 23.37 & $30.5 \%$ & 4.68 & 1.34 & 1.54 & 3.35 \\
\hline $\begin{array}{l}\text { GDP (US\$ } \\
\text { billion) }\end{array}$ & 32.48 & 101.14 & $32.1 \%$ & 23.63 & 4.38 & 7.00 & 12.91 \\
\hline $\begin{array}{l}\text { GDP Per Capita } \\
\text { (US\$) }\end{array}$ & 4,147 & 3,753 & & 5,241 & 2,847 & 3,927 & 3,498 \\
\hline $\begin{array}{l}\text { Export (US\$ } \\
\text { billion) }\end{array}$ & 11.6 & 90.83 & $12.8 \%$ & 37.5 & 4.36 & 18.9 & 6.35 \\
\hline $\begin{array}{l}\text { Utilized Foreign } \\
\text { Capital (US\$ } \\
\text { billion) } \\
\end{array}$ & 3.33 & 14.19 & $23.5 \%$ & 3.6 & 0.74 & 1.8 & 1.01 \\
\hline
\end{tabular}

Shanghai in the Yangtze River Delta (YRD) 2001

\begin{tabular}{|c|c|c|c|c|c|c|c|}
\hline & $\begin{array}{c}\text { Shanghai } \\
(\mathrm{SH})\end{array}$ & $\begin{array}{c}\text { Yangtze } \\
\text { River Delta } \\
\text { (YRD) }\end{array}$ & $\begin{array}{l}\% \text { of SH } \\
\text { in YRD }\end{array}$ & Wuxi & Suzhou & Nanjing & Ningpo \\
\hline Land area $\left(\mathrm{km}^{2}\right)$ & 6,341 & 100,113 & $6.3 \%$ & 4,650 & 8,488 & 6,598 & 9,365 \\
\hline $\begin{array}{l}\text { Registered Pop. } \\
\text { (million) }\end{array}$ & 13.27 & 74.94 & $17.7 \%$ & 4.36 & 5.8 & 5.53 & 5.43 \\
\hline $\begin{array}{l}\text { GDP (US\$ } \\
\text { billion) }\end{array}$ & 59.85 & $103.87^{*}$ & $57.6 \%$ & 16.45 & 21.28 & 13.91 & 15.86 \\
\hline $\begin{array}{l}\text { GDP Per Capita } \\
(\text { US } \$)\end{array}$ & 4,520 & $2,056^{*}$ & & 3,778 & 3,674 & 2,491 & 2,928 \\
\hline $\begin{array}{l}\text { Export (US\$ } \\
\text { billion) }\end{array}$ & 27.6 & 73.6 & $37.5 \%$ & 3.6 & 12.3 & 5.75 & 6.2 \\
\hline $\begin{array}{l}\text { Utilized Foreign } \\
\text { Capital (US\$ } \\
\text { billion) }\end{array}$ & 4.4 & 16.06 & $27.4 \%$ & 1.36 & 3.02 & 0.95 & 0.874 \\
\hline
\end{tabular}

*Estimated figure based on 2000 figure in the 2001 Statistic Yearbook for Chinese Counties (Cities)

Sources: Guangdong Statistic Bureau (2002); ChinaInfoBank (2004); Shanghai Statistics Bureau (2002); and Enright, et al. (2003). 